\title{
The effect of talent management on organizational performance improvement: The mediating role
} of organizational commitment

\author{
Mohammad Fathi Almaaitah ${ }^{a}$, Yousef Alsafadi ${ }^{a *}$, Shadi mohammad Altahat ${ }^{a}$ and Ahmad \\ mohmad Yousfi ${ }^{b}$
}

${ }^{a}$ Assistant professor, Jadara University, Jordan

${ }^{\text {bProfessor, Jadara University, Jordan }}$

CH R O N I C L E

\section{Article history:}

Received: March 17, 2020

Received in revised format:

March 302020

Accepted: March 30, 2020

Available online:

April 7, 2020

Keywords:

Talent Management

Normative commitment

Continuance commitment

Effective commitment

Organizational commitment

Transformational leadership style

\section{A B S T R A C T}

This study investigates the effects of talent management (TM) of human resources on organizational performance improvement. The study is accomplished through hypothesizing the effect of talent management on organizational performance. Organizational commitment is theorized to be a mediating factor for this relationship. In addition, the model considers transformational leadership style as a potential moderating factor. Data was collected from 385 Jordanian hotel employees using questionnaires and then analyzed using structural equation modeling (SEM). The results demonstrate the positive impact of talent management (TM) on organizational performance, effective continuance and normative commitment. It is also shown that effective continuance and normative commitment played a mediating role. Finally, Transformational leadership style is proven to be a moderating variable with an effect on talent management and organizational performance. The findings show the significance of the role that organizational commitment plays in achieving human resources performance goals.

\section{Introduction}

This research examines human resource management in hospitality and tourism hotels which compete fiercely between each other in order to provide better service in the best possible way. The changes being done in the hotels were for the purpose of seeking and employing qualified human resources for improving the services and reputation of these hotels in order to secure future financial gains. Therefore, some hotels have established a new department, which is talent management (TM). There is a consensus that TM is the achievement of incorporated strategies or systems intended to improve the recruitment and development processes of individuals and to hold on to those with the required skills and prepare to meet existing and prospect organizational needs (Collings \& Mellahi, 2009). TM concentrates on the future needs of the organization. It works within a strategic method to achieve the company's future goals by assigning jobs that are important for growth and development and selecting the best candidates for these jobs (Almaaitah et al., 2015). If companies want to develop leaders from within their current talent pool and have the free time and resources required to establish a beneficial and effective TM program, it would become an essential component of a long-term strategy for human capital. Organizations all over the world have been facing various challenges in attracting talented and intelligent human resources, which are considered a valuable resource in the organizational structure. To that end, they began to develop strategies and means for managing talent, linking it to development plans for future procurement of human resources for system development. Organizations have also began suggesting the mechanisms necessary for providing the appropriate regulatory environment for the growth of their talent and leadership 
(Almaaitah et al., 2017; Michaels, Handfield \& Axelrod, 2001). The increase in challenges and the strength of rivalry faced by institutions and the necessity nowadays to strive to achieve superiority and distinction has led to these organizations seeking to possess a high and distinct type of talented human resources with high capabilities and superior skills, as the resource able of innovation, creativity, excellence and the leadership of the organization towards success. This, in particular, has led to the appearance of a new approach, which is TM. In the framework of the continuous quest to improve and develop the current performance of the institution, organizational, human and technical factors interfere to affect the degree of improvement performance (Lewis \& Heckman, 2006). This paper contains the following: First, the theoretical literature behind the subject of the study is reviewed. Second, the procedures used in data analysis were explored. Third, the final results of the paper were presented. Finally, the study's findings are demonstrated and discussed.

\section{Literature review}

\subsection{Talent Management}

Talent Management TM is an incorporated strategy or system planned to develop the recruitment, selecting and improvement processes of people and to hold on to those with the required skills and is frequently explored in the presence of a companywide plan in the long term that is closely connected with the general business goals of the organizations, and human resources are more valued, (Beechler \& Woodward, 2009). What is known as talent management appeared in the beginning of the nineties of the last century. During that time, intense competition raged between large companies, and some companies were trying to attract employees with high qualifications and others were trying to preserve their efficient human resources and their development, when this concept became an important part of modern management system and one of the organizational development and change strategies (Thunnissen et al., 2013). Talent in the twenty-first century, being characterized by high speed and competitiveness, has become one of the most vital pillars which companies and organizations rely on in achieving their strategic vision, not to mention that the demand for it has increased. Starting with a good selection of qualified employees and discovering, developing and maintaining their talents can confer a competitive advantage that enables organizations to easily achieve their goals (Doh et al., 2011).

The following hypotheses are proposed:

$\mathbf{H}_{1}$ : Talent management has a positive influence on organizational performance in the hotel sector of Jordan.

$\mathbf{H}_{2}$ : Talent management has a positive influence on the organizational commitment within the hotel sector of Jordan. To be more specific, this influence is studied through investigating the following:

$\mathbf{H}_{2 \mathrm{a}}$ : Affective commitment is positively impacted by talent management.

$\mathbf{H}_{2 \mathbf{b}}$ : Continuance commitment is positively impacted by talent management.

$\mathbf{H}_{\mathbf{2}}$ : Normative commitment is positively impacted by talent management.

\subsection{Organizational Performance}

Organizational performance is defined as the outcome of all operations carried out by the organization, and it is a reflection of how the organization uses its resources and investments in a way that makes it able to achieve its goals. The organizational performance, according to the comprehensiveness criterion, can be divided into the following (Daft, 2012).

1- Overall performance: It is embodied in the accomplishments that all the functions and subsystems of the organization have contributed to achieving without a single part or unit of unity in achieving them, and through the overall performance it is possible to judge the extent to which the organization has achieved and attained its general goals such as continuity, growth and profitability.

2- Partial Performance: It refers to the performance that is achieved at the level of the organization's subsystems and their primary functions, as each sub-system seeks to achieve its own goals, not the goals of other systems. By achieving the sum of the subsystem performances, the overall performance of the organization is achieved.

The importance of measuring organizational performance emerges through monitoring and knowing the activity and nature of the economic institution, following up and knowing the financial and economic conditions surrounding it, and assisting in the process of analysis, comparison and evaluation of financial data, as well as helping to how financial data, and measuring organizational performance are related. Studying this relationship constitutes Financial analysis, which is defined as a series of financial methods that can be used to determine the strength and weakness of the institution and which uses financial ratios in the analysis for the purposes of comparing past performance with current and expected performance. The importance of measuring organizational performance can be summarized in the following points (Simsek, Z., 2007; Gregory et al., 2007).

1. Measuring performance develops interior communications among workers, as well as exterior communications among the organization and its clients and customers. 
2. Measuring performance's level can indicate the extent to which the institution is addressing the requests of society by building progress towards achieving the institution's goals.

3. The "measurement process" focuses attention on what must be accomplished and pushes institutions to provide the resources, time, and efforts needed, and to attract and preserve talents to achieve goals. That measurement also provides feedback on the track of development towards goal achievement and ascertaining how the findings differ from the goals. For this reason, the organizations can work on analyzing performance gaps and making adjustments.

\subsection{Organizational Commitment}

There is a bond that employees' experience in the context of their organization, and this bond is called organizational commitment. Organizational commitment refers to "the employee's emotional attachment to, identification with, and involvement in the organization" (Malik et al., 2010). In general, if the employees feel a commitment to the organization they work in, they would feel a connection with that organization. They would feel a genuine understanding of the goals of their organization, and feel like a part of it. These employees tend to be more loyal to their work, which is an added virtue. They also tend to be relatively extremely productive and more willing to offer help and support (Steyrer et al., 2008).The employees' organizational commitment is a key factor in increasing the productivity and efficiency of an organization (Salleh et al., 2016). Natalie Allen and John Meyer developed the three component "Model of Commitment", which was published in the "Human Resource Management Review" in 1991.The model describes commitment to an organization as a psychological state, and there are three factors that make up the way that employees feel towards their organization (Meyer \& Allen, 1991).

The Model's three components are:

1. Affective Commitment: This happens when we experience a strong and emotional attachment to the organization we work for, and to the job that we work in. This would make we want to be in the organization and really feel the passion to commit to the organization's values and goals (Meyer \& Allen, 1991).

2. Continuance Commitment: We can commit to the organization to the point that we fear leaving it, as we fear the loss of benefits, and when we compare the pros and cons of departing our organization, we would feel the need to stay rather than get a new role (Faloye, 2014). There are three types of losses: monetary (a loss of benefits or salary), professional (loss of role-related skills or seniority), or social (loss of acquaintances and friends).

3. Normative Commitment: It is the commitment that happens when we have a sense of belonging to the organization, so that even if we were unsatisfied with our current role or pursuing other ones, we would feel obliged to your current organization and feel the need to stay (Messner, 2013).

Regarding the previous, the following hypotheses are proposed:

H3: Organizational commitment positively impacts the organizational financial performance of the hotels. In order to understand the impact, the three components of commitment were studied the following were proposed:

$\mathbf{H}_{3 \mathbf{a}}$ : Affective commitment positively impacted organizational financial performance.

$\mathbf{H}_{3 \mathbf{b}}$ : Continuance commitment positively impacted organizational financial performance.

$\mathbf{H}_{3 \mathbf{c}}$ : Normative commitment positively impacted organizational financial performance.

H4: Organizational commitment mediates the connection between the organization performance of the hotels and talent management. Thus, the following hypotheses are proposed:

$\mathbf{H}_{4 \mathrm{a}}$ : The relationship between the organization performance of the hotels and talent management is mediated by affective commitment.

$\mathbf{H}_{4 \mathrm{~b}}$ : The relationship between the organization performance of the hotels and talent management is mediated by continuance commitment.

$\mathbf{H}_{4 \mathrm{c}}$ : The relationship between the organization performance of the hotels and talent management is mediated by normative commitment.

\subsection{Transformational Leadership}

Transformational leadership in this research is used in a way which permits for more varied possibilities for studying its moderation of the theorized effect of talent management in improving organizational performance. An example of this is that employees look to shared visions to provide an optimal course of action to reach the organizational goals (Galli, 2019). Leaders act as role models to the employees. They also use their charisma in order to promote certain behavioral attitude among employees. Leaders also motivate and give inspiration by showing off a clearer and more attention-grabbing vision. Other roles of the leaders are individualized consideration and intellectual stimulation. These roles are thought to mediate the effect of talent management in improving organizational performance (Hussein \& Çağlar, 2019). The theory of Transformational leadership is seen as different from the other current theories and preceding ones, based on its ability to tie in the greater good as it requires the participation of employees in processes or activities that are correlated to the private aspect of the directions 
of the organization and the route that will be produced is particularly social. Transformational leaders increase the motivation and ethics for both leaders and employees (Shamir, House, \& Arthur, 1993). Accordingly, a "transformational leader" is a leader that attempts to stimulate employees to change their needs by surpassing self-interests and struggling for advanced order needs. This theory is aligned with Maslow's (1954) theory of upper order needs. "Transformational leadership" is a path that pursues and adapts goals based on beliefs, values, and attitudes that give highlight to leadership practices and their ability to apply changes (Shadi \& Atan, 2018). Based on the literature surrounding transformational leadership, the following hypothesis is proposed

H5: Transformational leadership moderates the relationship between talent management and organizational performance of the hotels.

\subsection{Conceptual framework}

This model was made based on the review of the literature for this paper and is shown in Fig. 1.

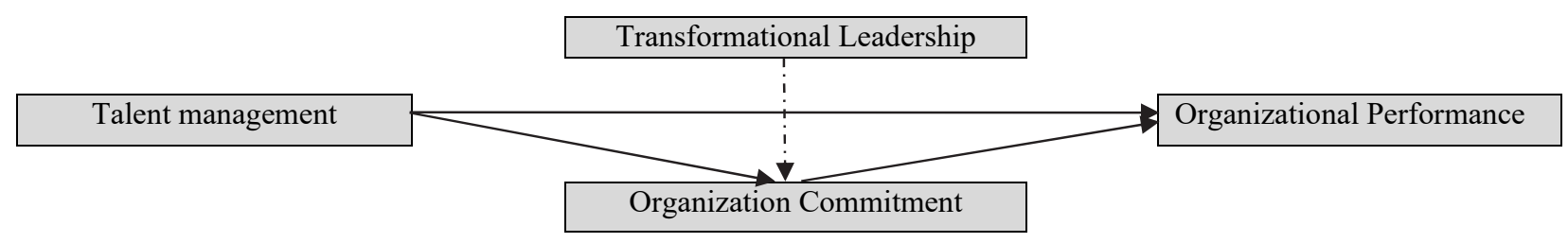

\section{Methodology}

Fig. 1. Research conceptual framework

\subsection{The study's design and data collection}

Researchers collected the data from workers in the Jordanian hotel sector. In our research 5- and 4-star hotels were targeted; 424 envelopes were collected from the 1005 distributed questionnaires. Irrelevant responses were deleted by using a list that cleans up the missing data from the data set. The analysis used 385 responses from the final data set.

\subsection{Constructs measurement}

Based on previous studies, work has been done to develop a questionnaire prepared and specialized for this paper from the leading literature and previous studies. Using the Likert-5 scale, talent management was evaluated using 23 items adapted from Collings and Mellahi (2009) and Lewis and Heckman (2006). Organizational commitment was evaluated using 12 items adapted from Salleh et al. Using 7 adapted items, transformation leadership was also measured (Nielsen et al., 2008; Hussein \& Çağlar, 2019).

\section{Data analysis}

Here, the data collected from the survey was analyzed. First, the researcher used frequency descriptive analysis to analyze demographic information. Second, data analysis was done for each variable and its indicators. Thirdly, hypotheses created using structural equation modeling (SEM) were tested. So as to understand and rephrase the gathered knowledge in a simpler way, SPSS and AMOS software were employed. Furthermore, the mediation and moderation effects were gauged using descriptive statistical techniques. An SEM technique was adopted due to the conceptual research framework's nature, given that SEM is the method most often used in strategic human resource management research (Ringle et al., 2018). Using SEM, Researchers are able to evaluate the relationships between multiple dependent and independent constructs in a structural model in order to jointly test interrelated hypotheses (Gefen \& Straub, 2000). In this research AMOS was used for investigating the measurement and structural models.

\subsection{Descriptive analysis}

Regarding gender, the majority of the respondents were found to be males, as they made up about $84 \%$, while females represented only $16 \%$ according to Fig. 2 . The reason this gender composition was formed this way was likely the fact that females were less willing to respond to the questionnaires than males. The respondent's marital status was found to be more leaning towards 'married', as married people made up about $51 \%$ while singles only stood for $47 \%$, and $2 \%$ were divorced. As shown in figure, low-level front-line staff at the hotel were the main respondents, making up $62 \%$, while middle-level managers made up $18 \%$ of the respondents. Also, higher-level managers had a lower percentage, as they made up only $12 \%$ of the respondents, but this was more than the specialists in the human resources department, who made up only $8 \%$. The "demographic characteristics" of job experience were distributed as follows: respondents mostly had sufficient work experience as $56 \%$ of them had 1-5 years of work experience, while employees who had less than one year made up only $25 \%$. Those who have worked for more than 11 years made up 14\%, and those who worked from 6 years to less than 10 years made up $5 \%$ of the respondents. 


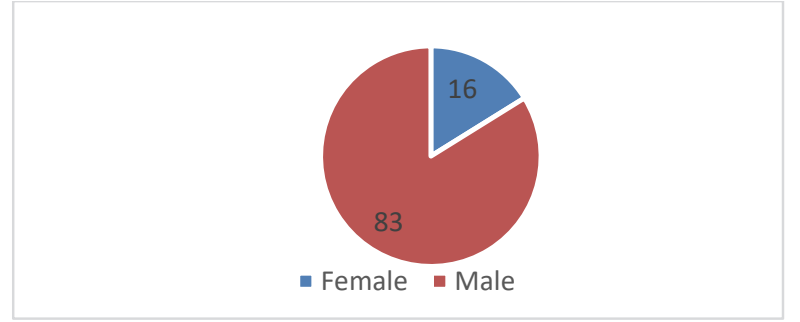

Gender

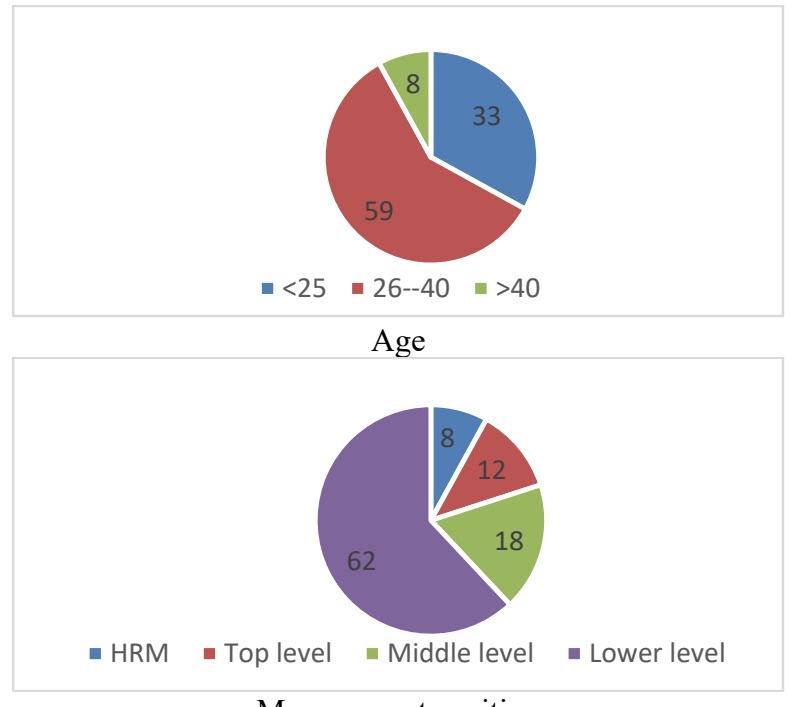

Management position

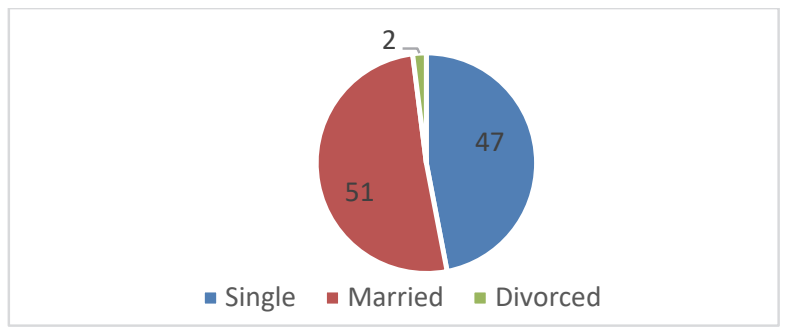

Marital status

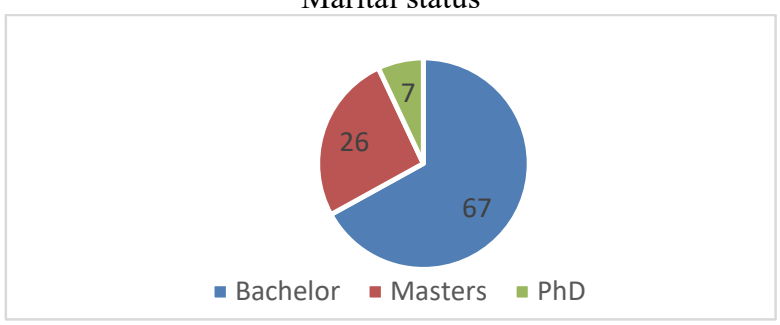

Educational background

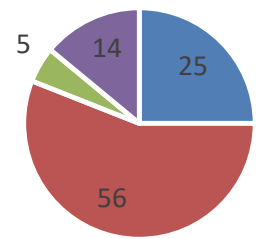

- 1 - $1--5=6--10 \quad \square>10$

Years of job experience

Fig. 2. Personal characteristics of the participants in percentage

\subsection{Model Measurement}

The researchers carried out a "confirmatory factor analysis" (CFA). CFA is a statistical technique applied to confirm the factor loadings of "observed variables" (Bagozzi \& Yi, 1988). Moreover, the CFA technique illustrates "construct validity" (discriminant, nomological, and convergent validity). Then, CFA was carried out for the entire model.

Table 1

CFA: standardized loading factors, AVE, CR, Cronbach's $\alpha$

\begin{tabular}{|c|c|c|c|c|c|}
\hline Variable & Description & $\lambda$ & AVE & CR & $\alpha$ \\
\hline \multirow{4}{*}{$\begin{array}{l}\text { Organizational } \\
\text { performance }\end{array}$} & The hotel's management is keen to improve the operational efficiency of its various operations. & .887 & \multirow{4}{*}{0.841} & \multirow{4}{*}{0.955} & \multirow{4}{*}{0.941} \\
\hline & The hotel's management is working to improve research and development. & .935 & & & \\
\hline & The management of the hotel is characterized by the speedy handling of employee complaints and suggestions. & .912 & & & \\
\hline & The hotel management contributes to providing moral support for employees to perform better. & .931 & & & \\
\hline \multirow{6}{*}{$\begin{array}{l}\text { Normative } \\
\text { commitment }\end{array}$} & I feel proud to be a member of this hotel. & .729 & \multirow{6}{*}{0.639} & \multirow{6}{*}{0.911} & \multirow{6}{*}{0.899} \\
\hline & I make sure to provide my best performance for this hotel. & .812 & & & \\
\hline & The individual's presence in this hotel is an indication of his competence. & .859 & & & \\
\hline & I consider the hotel's problems my problems personally. & .832 & & & \\
\hline & My hotel deserves loyalty from its staff. & .771 & & & \\
\hline & I feel a sense of belonging to my hotel as if it were my own home & .756 & & & \\
\hline \multirow{6}{*}{$\begin{array}{c}\text { Talent } \\
\text { management }\end{array}$} & The hotel has attractive salaries and incentives for talented people to work for the hotel. & .722 & \multirow{6}{*}{0.563} & \multirow{6}{*}{0.867} & \multirow{6}{*}{0.890} \\
\hline & Directly, the hotel searches for those with expertise and, competence to fill important senior positions & .863 & & & \\
\hline & The hotel adopts a culture of employing talented employees and those with expertise and competencies. & .887 & & & \\
\hline & The hotel depends on highlighting the role of the gifted and facilitating their mission inside and outside the hotel. & .793 & & & \\
\hline & $\begin{array}{l}\text { The management of the hotel seeks to increase the knowledge and expertise of talented employees by participat- } \\
\text { ing in scientific seminars and courses inside and outside the hotel. }\end{array}$ & .783 & & & \\
\hline & The hotel provides a lot of modern technology to talents for more creativity and innovation. & .723 & & & \\
\hline \multirow{6}{*}{$\begin{array}{l}\text { Transforma- } \\
\text { tional } \\
\text { Leadership } \\
\text { style }\end{array}$} & My leaders convey a positive and clear vision of the future. & .743 & \multirow{6}{*}{0.507} & \multirow{6}{*}{0.856} & \multirow{6}{*}{0.844} \\
\hline & My leaders treat workers as individuals, and encourage their development. & .753 & & & \\
\hline & My leaders support staff empowerment. & .836 & & & \\
\hline & My leaders encourage involvement, trust, and cooperation among staff. & .758 & & & \\
\hline & My leaders support solving problems in new ways & .581 & & & \\
\hline & My leaders are obvious about their practices and values. & .538 & & & \\
\hline \multirow{5}{*}{$\begin{array}{l}\text { Continuance } \\
\text { commitment }\end{array}$} & The presence of the individual in this hotel is an indication of his competence. & .862 & \multirow{5}{*}{0.679} & \multirow{5}{*}{0.915} & \multirow{5}{*}{0.920} \\
\hline & It is unethical to move from one organization to another. & .924 & & & \\
\hline & I am not frightened what would happen if I give up my work without one lined up. & .868 & & & \\
\hline & If I get another job with a better salary, I would not like to leave my hotel. & .717 & & & \\
\hline & It might not be too costly for me to quit my hotel now. & .735 & & & \\
\hline \multirow{5}{*}{$\begin{array}{l}\text { Affective } \\
\text { commitment }\end{array}$} & I have strong feeling of fit in to my hotel. & .777 & \multirow{5}{*}{0.516} & \multirow{5}{*}{0.846} & \multirow{5}{*}{0.862} \\
\hline & I feel proud to say that I work at my hotel. & 699 & & & \\
\hline & Being at my hotel has personal meaning to me. & .787 & & & \\
\hline & I feel personally attached to my work hotel. & .536 & & & \\
\hline & I pleased to retire at my hotel. & .672 & & & \\
\hline
\end{tabular}


According to Table 1, the "convergent validity" of model found in "composite reliability" (CR) has appeared above the threshold of 0.70 on every scale item, which implies fairness level of convergent validity (Hair, 2010). Also, Cronbach's alpha $(\alpha)$, has been used to test the reliability and as we can observe from the table the threshold of this number is 0.60 . In addition, the loading factors shown in the table are more than 0.5 which indicate a satisfactory level model fit. Also, "Average variance extract" (AVE) appeared above the threshold of 0.50 . According to Table 2, the data demonstrated a good fit as it is shown below in which model fit index were applied to investigate the Confirmatory Factor Model.

Table 2

CFA, goodness of fit index

\begin{tabular}{|c|c|c|c|}
\hline Measures & Estimates & Cutt-off Threshold & Explanation \\
\hline CMIN & 2573.876 & -- & -- \\
\hline $\mathrm{DF}$ (degree of freedom) & 1364.000 & -- & -- \\
\hline SRMR & 0.053 & $<0.08$ & Excellent \\
\hline CMIN/DF & 1.880 & 1 to 3 & Excellent \\
\hline RMSEA & 0.046 & $<0.06$ & Excellent \\
\hline CFI & 0.906 & $>0.95$ & Acceptable \\
\hline PClose & 0.815 & $>0.05$ & Excellent \\
\hline
\end{tabular}

\subsection{Structural Model}

First the structural model was applied and then the measurement model. And as stated before, SEM was selected for the nature of the study model.

\subsubsection{Direct effects}

Regarding $\mathrm{H}_{1}$, which proposed that TM had a direct positive effect on organizational performance $(\mathrm{OP})$, the results $(\beta=$ $2.241, \mathrm{p}<0.591^{* * *}$ ) indicate that $\mathrm{H}_{1}$ was accepted. Then, $\mathrm{H}_{2 \mathrm{a}}$ pointed towards the fact that $\mathrm{TM}$ had a direct positive impact on the "emotional commitment" which is the first component of organizational commitment, and it was calculated that ( $\beta=$ $0.239, \mathrm{p}<0.013$ ), therefore, $\mathrm{H}_{2 \mathrm{a}}$ was accepted. Regarding $\mathrm{H}_{2 \mathrm{~b}}$ which assumed a positive effect of talent management on the "continuance commitment" and is the second component of organizational commitment we have $\left(\beta=0.723, p<0.211^{* * *}\right)$, thus, $\mathrm{H}_{2 \mathrm{~b}}$ was accepted. The results demonstrated that there was no effect of talent management on the "normative commitment" which is the third component of organizational commitment as it was calculated that $(\beta=-0.021, p<0.828)$, and therefore, $\mathrm{H}_{2 \mathrm{c}}$ was rejected. Regarding $\mathrm{H}_{3 \mathrm{a}}$, a direct positive effect of "affective commitment" on OP was found $(\beta=0.218$, $\mathrm{p}<0.0041)$, so H3a was accepted. Then regarding $\mathrm{H}_{3 \mathrm{~b}}$ it was calculated that $(\beta=0.147, \mathrm{p}<0.0061)$ which indicated that "continuance commitment" had a significant direct impact on OP, so $\mathrm{H}_{3 \mathrm{~b}}$ was accepted. On the other hand, $\mathrm{H}_{3 \mathrm{c}}$ predicted a negative impact of "normative commitment" on OP $\left(\beta=-0.515, \mathrm{p}<-0.30^{* * *}\right)$, thus, $\mathrm{H}_{3 \mathrm{c}}$ was negatively accepted. These findings are explained below in Table 3.

Table 3

Direct hypothesis testing

\begin{tabular}{|c|c|c|c|c|}
\hline Hypothesized relations & Estimate & $\mathrm{CR}$ & $P$ & Result \\
\hline H1. T M $\rightarrow$ Organizational performance & 2.239 & 15.213 & $0.59 * * *$ & Accepted \\
\hline H2a. T M $\rightarrow$ Affective commitment & 0.237 & 2.447 & 0.014 & Accepted \\
\hline$H 2 b . \mathrm{T} \mathrm{M} \rightarrow$ Continuance commitment & 0.724 & 4.252 & $0.21 * * *$ & Accepted \\
\hline H2c. T M $\rightarrow$ Normative commitment & -0.020 & -0.219 & 0.827 & Rejected \\
\hline$H 3 a$. Affective $\rightarrow$ OP & 0.217 & 2.905 & 0.004 & Accepted \\
\hline$H 3 b$. Continuance $\rightarrow$ OP & 0.148 & 2.733 & 0.006 & Accepted \\
\hline$H 3 c$. Normative $\rightarrow$ OP & -0.515 & -6.282 & $-0.30 * * *$ & Accepted \\
\hline
\end{tabular}

\subsubsection{Indirect (mediation) effects}

In accord with Baron and Kenny's findings for checking the mediation effects, this study found that "affective commitment" $(\beta=0.051, p<0.014)$ displayed partial mediation effect while "normative commitment" $(\beta=0.105, p<0.003)$ didn't show any mediation effects as revealed below in Table 4. Therefore, H4a and H4b had been accepted while H4c wasn't accepted.

Table 4

Indirect (mediation) results

\begin{tabular}{llrl}
\hline \multicolumn{1}{c}{ Hypothesized relations } & Estimates & $P$ & Mediation \\
\hline$H 4 a$. HIWS $\rightarrow$ Affective $\rightarrow$ OP & $\beta=0.051$ & $\mathrm{P}=0.013$ & (Partially) mediated \\
$H 4 b$. HIWS $\rightarrow$ Continuance $\rightarrow$ OP & $\beta=0.105$ & $\mathrm{P}=0.002$ & (Partially) mediated \\
$H 4 c$. HIWS $\rightarrow$ Normative $\rightarrow$ OP & $\beta=0.011$ & $\mathrm{P}=0.815$ & Not mediated \\
\hline
\end{tabular}

\subsubsection{Moderation}

Regarding $\mathrm{H}_{5}$, the findings revealed in Table 5 below, pointed out that transformational leadership style diminished the positive effect that talent management had on $\mathrm{OP}\left(\beta=-0.148, \mathrm{p}<-0.15^{* * *}\right)$, So $\mathrm{H}_{5}$ was accepted. Fig. 3 explains the impact of transformational leadership style on the bond between TM and OP and shows that TM related with a greater transformational leadership diminished the positive impact TM has on OP. 
Table 5

Interaction impact of transformational leadership

\begin{tabular}{lcccc}
\hline Hypothesized relations & Estimates & CR & $P$ & Result \\
\hline Interaction effect & & & & \\
\hline H5. T M XX Transformational Leadership style $\rightarrow$ OFP & -0.1481 & -4.372 & $0.151^{* * *}$ & Was Supported \\
\hline
\end{tabular}

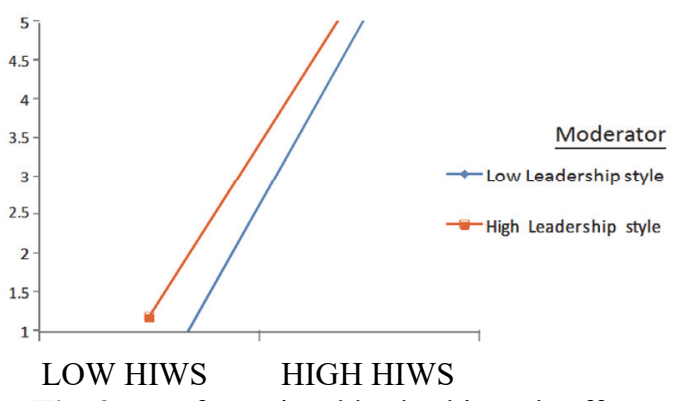

Fig. 3. transformational leadership style effect

\section{Discussions}

This paper was made for the purpose of investigating the effect of talent management on organizational performance, and that was done by having opened the black box through organization commitment. This research was accomplished due to the vast quantity of demands for looking into novel models in SHRM, and particularly in the hotel and hospitality sector (Madera et al., 2017). By doing that, we have covered what was not covered in the literature. This was performed by investigating transformational leadership style as a moderator in this study's model. The purpose of doing so, in the context of the hospitality and tourism sector in Jordan, is to increase the impact TM has on OP. A suitable term that describes the commitment an organization was hiring, managing, improving, and obtaining skilled employees called TM. Employees in question are expected to improve OP. We were able to confirm that hotels could increase the quality of employees and build OP when implementing TM $\left(\mathrm{H}_{1}\right)$, and that can be seen most when implementing it in the organizational commitment framework of applied affective, continuance and normative commitment. The finding is further confirmed by the results of Meyer and Allen (1990), where they discovered a direct positive relationship among OP and TM. Our findings, however, gave a new outlook as the first research concerning this within the tourism and hospitality sector, showing the impact that TM has in improving OP. We had, by pursuing a more general framework of TM, also contributed to the strategic HRM literature. This was done by breaking down the model mediation into organizational commitment, whose aim was to improve organizational and employee performance.

\subsection{Implications}

The researchers investigated and built a model showcasing, in the Jordanian hospitality and tourism sector, the impact that TM had on OP. Previous research explored the impact of TM on OP improvement in the banking sector (Hilal, 2012). Other researchers also studied it in India's context (Kaur, 2013). Some previous researchers have also found that TM shows no impact at all on OP improvement in German firms (Ralf \& Tony, 2010). Because of this, the researchers in this study have found that TM impacted OP in Jordanian contexts positively. This aligned with the previous research where researchers deduced that OP and TM were correlated positively.

\subsection{Research limitations and future recommendations}

The cross-sectional research design is one of our first limitations as the big impact TM has in improving OP is different depending on the time of the collection of data. Henceforth, we encourage future research in performing a longitudinal study design, this is in the hopes of gaining a deeper insight into the correlation between organizational commitment, TM, and transformational leadership, and how these can enhance and increase the quality of OP. Other research designs can also be investigated, such as causality relationship. The researchers strongly wish that in future research other mechanisms may be incorporated in showcasing and giving an explanation of the impact talent management has on organizational performance improvement beyond organizational commitment. The idea of the "black box" will be investigated for studying the impact talent management has on organizational performance improvement in these studies. As a final note, this research was done in the field of the Jordanian hospitality and tourism industry, because of this, the outcome can be different than studies in other industries, such as manufacturing industries or other service sectors working in different contexts than the Jordanian context by making the outcome simplified and set in a more general form. Therefore, further studies, must explore these limitations in the hopes of providing more knowledge on the nature of the impact talent management has on organizational commitment and organization performance improvement. 


\section{References}

Almaaitah, M. F., Harada, Y., \& Bin, M. F. (2015). Core principles for talent management system and its impact on competitive advantage: Applied study cellular communications companies in Jordan. International Journal of Academic Research in Business and Social Sciences, 5(6), 2222-6990.

Almaaitah, M. F., Harada, Y., Sakdan, M. F., \& Almaaitah, A. M. (2017). Integrating Herzberg and Social Exchange Theories to Underpinned Human Resource Practices, Leadership Style and Employee Retention in Health Sector. World Journal of Business and Management, 3(1), 16.

Altahat, S., \& Atan, T. (2018). Role of healthy work environments in sustainability of goal achievement; ethical leadership, intention to sabotage, and psychological capital in Jordanian universities. Sustainability, 10 (10), 3559.

Bagozzi, R., \& Yi, Y. (1988). On the Evaluation of Structural Equation Models. Journal of the Academy of Marketing Sciences, 16, 74-94.

Beechler, S., \& Woodward, C. (2009). The global "war for talent". Journal of International Management, 15(3), $273-285$.

Collings, D. G., \& Mellahi, K. (2009). Strategic talent management: A review and research agenda. Human Resource Management Review, 19(4), 304-313.

Daft, R. (2012). Organization theory and design (11th ed.). Mason, OH: South-Western.

Gregory, D. M., Way, C. Y., LeFort, S., Barrett, B. J., \& Parfrey, P. S. (2007). Predictors of registered nurses' organizational commitment and intent to stay. Health Care Management Review, 32(2), 119-127.

Doh, P., Stumpf, S., \& Tymon, W. (2011). Supplement 1: Responsible Leadership. Journal of Business Ethics, 98, 85-100.

Faloye, D. O. (2014). Organizational commitment and turnover intentions: Evidence from Nigerian paramilitary organization. International Journal of Business \& Economic Development, 2(3), 23-34.

Galli, B. J. (2019). A shared leadership approach to transformational leadership theory: Analysis of research methods and philosophies. In Scholarly Ethics and Publishing: Breakthroughs in Research and Practice (pp. 751-790). IGI Global.

Gefen, D., Straub, D., \& Boudreau, M. C. (2000). Structural equation modeling and regression: Guide-lines for research practice. Communications of the Association for Information Systems, 4(1), 7.

Hilal, M. (2012). Talent management. Improve performance and development publication and distribution. Cairo.

Hussein, Y., \& Çağlar, D. (2019). The effect of high involvement work systems on organizational performance: The mediating role of knowledge-based capital. Management Science Letters, 9(9), 1361-1372.

Lewis, R. E., \& Heckman, R. J. (2006). Talent management: A critical review. Human Resource Management Review, 16(2), 139154.

Madera, J. M., Dawson, M., Guchait, P., \& Belarmino, A. M. (2017). Strategic human resources management research in hospitality and tourism: A review of current literature and suggestions for the future. International Journal of Contemporary Hospitality Management, 29(1), 48-67.

Malik, M. E., Nawab, S., Naeem, B., \& Danish, R. Q. (2010). Job satisfaction and organizational commitment of university teachers in public sector of Pakistan. International Journal of Business and Management, 5(6), 17

Maslow, A. H. (1954). Motivation and personality. New York: Harper and Row.

Meyer, J. P., \& Allen, N. J. (1991). A three-component conceptualization of organizational commitment. Human Resource Management Review, 1(1), 61-89.

Messner, W. (2013). Effect of organizational culture on employee commitment in the Indian IT services sourcing industry. Journal of Indian Business Research, 5(2), 76-100.

Michaels, E., Handfield-Jones, H., \& Axelrod, B. (2001). The war for talent. Boston, Mass: Harvard Business School Press.

Nielsen, K., Yarker, J., Brenner, S. O., Randall, R., \& Borg, V. (2008). The importance of transformational leadership style for the well-being of employees working with older people. Journal of Advanced Nursing, 63(5), 465-475.

Ralf, B., \& Tony, R. (2010). Talent on demand? Talent management in the German and Irish subsidiaries of a US multinational corporation. Personnel Review, 39, 414-431.

Ringle, C. M., Sarstedt, M., Mitchell, R., \& Gudergan, S. P. (2018). Partial least squares structural equation modeling in HRM research. The International Journal of Human Resource Management, 1-27.

Salleh, S. M., Zahari, A. S. M., Said, N. S. M., \& Ali, S. R. O. (2016). The influence of work motivation on organizational commitment in the workplace. Journal of Applied Environmental and Biological Sciences, 6(5S), 139-143.

Shamir, B., House, R. J., \& Arthur, M. B. (1993). The motivational effects of charismatic leadership: A self-concept based theory. Organization Science, 4(4), 577-594.

Simsek, Z., (2007). CEO tenure and organizational performance: an intervening model, Strategic Management Journal, 28(6), 653662

Steyrer, J., Schiffinger, M., \& Lang, R. (2008). Organizational commitment: A missing link between leadership behaviour and organizational performance?. Scandinavian Journal of Management, 24(4), 364-374.

Thunnissen, M., Boselie, P., \& Ben Fruytier, B. (2013). A review of talent management: 'infancy or adolescence?', The International Journal of Human Resource Management, (24,9), 1744-1761.

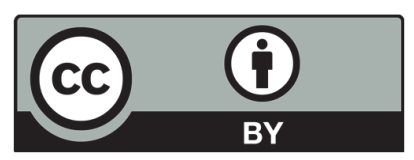

(C) 2020 by the authors; licensee Growing Science, Canada. This is an open access article distributed under the terms and conditions of the Creative Commons Attribution (CC-BY) license (http://creativecommons.org/licenses/by/4.0/). 